\title{
ANALYSIS OF POSSIBLE APPLICATION OF HIGH-TEMPERATURE NUCLEAR REACTORS TO CONTEMPORARY LARGE-OUTPUT STEAM POWER PLANTS ON SHIPS
}

\author{
T. Kowalczyk, M.Sc. ${ }^{a}$ \\ J. Głuch, Prof. ${ }^{b}$ \\ P. Ziółkowski, M.Sc. ${ }^{a}$ \\ ${ }^{a}$ Institute of Fluid Flow Machinery, Polish Academy of Sciences, Poland \\ ${ }^{\mathrm{b}}$ Gdańsk University of Technology, Poland
}

\begin{abstract}
This paper is aimed at analysis of possible application of helium to cooling high-temperature nuclear reactor to be used for generating steam in contemporary ship steam-turbine power plants of a large output with taking into account in particular variable operational parameters. In the first part of the paper types of contemporary ship power plants are presented. Features of today applied PWR reactors and proposed HTR reactors are discussed. Next, issues of load variability of the ship nuclear power plants, features of the proposed thermal cycles and results of their thermodynamic calculations in variable operational conditions, are presented.
\end{abstract}

Keywords: ship power plants, steam turbines, nuclear reactors, PWR, HTR, variable operational conditions

\section{INTRODUCTION}

Structure of contemporary world economy demands to make use of developed transport by sea. Therefore is today observed an increasing number of orders for carrying goods by sea as well as increasing average load carrying ability of containerships, bulk carriers and tankers [1]. The changes determine development of ship power plants, aimed at moderating detrimental impact on the environment, improving energy conversion efficiency as well as economic indices [24]. The aims can be reached by applying balanced energy conversion which becomes more and more popular both in the case of conventional fuels and alternative ones [2]. As far as sea transport has been concerned this means perfecting the combustion engine power plants and combined systems $[3,11,12]$, improving operational parameters of gas turbines [13] and steam thermal cycles [8], developing novel systems based on fuel cells - SOFC [14] as well as making use of nuclear energy [15]. Special attention should be paid to HTR nuclear reactors. This is a prospective, fast developing solution both for power industry and sea transport $[4,16,19,21]$.
This work is aimed at making analysis of possible profits, in thermodynamic and operational aspects, resulting from application of HTR reactors into ship nuclear power plants of a large output with taking into account load variability, in particular. For this reason calculations of selected power plant parameters in function of changes in generated effective power have been conducted for two selected thermal cycles of ship steam power plants.

\section{TYPES OF PRESENTLY USED SHIP POWER PLANTS}

Contemporary ship power plants of a large output are usually fitted with two-stroke low- speed diesel engines. Engines of the type, i.e. internal-combustion ones, are characterized by a high efficiency of the order of $51 \%$ $[3,11,12]$. Their huge popularity in shipbuilding results from economic conditions, namely, relatively low investment cost , low specific fuel combustion, possible charging with cheap heavy fuel oil. Moreover the engines under consideration 
are of favourable external characteristics and low rotational speeds. In the case of the largest merchant ships it is possible to couple directly together screw propeller and engine shaft omitting this way any reduction gear. This is reached in expense of ship's manoeuvrability. Piston engines have also some disadvantages such as large mass of power plant , generation of nuisance vibration, long start-up period as well as emission of gas black and sulphur oxides in case of heavy oil charging. Aspects of emission of noxious substances negatively influence profitability of low-speed engines as regulations limiting exhaust gas emission level become more and more restrictive $[3,11,12,14]$.

Gas and steam turbine engines are applied in shipbuilding less often. Turbine engines are characteristic of a high ratio of power output to mass of power plant, generation of high frequency vibrations (in contrast to piston engines, there occur no nuisance vibration but high frequency noise difficult to be damped) $[3,11]$. Additionally, gas turbines can be very fast started hence ship can reach full serviceability much faster $[2,11]$, as well as no "running-in" period is necessary [9]. And, as far as boilers producing steam for steam turbines are concerned they are capable of burning various fuels. Additionally, in the case of steam power plants pumps and compressors can be directly fed with steam, that makes mass of auxiliary devices lower $[9,12,13]$. Among drawbacks of both the types of turbine engines, can be numbered a greater specific fuel combustion (compared to diesel engines), high rotational speeds, that makes application of reduction gear necessary $[9,10,13]$. The above mentioned features resulted in that gas turbines have found their application first of all to combat vessels and fast passenger boats, whereas steam power plants - to the largest cargo ships, gas tankers and ships of nuclear propulsion [13]. The last particular case dealing with ship large-output steam power plants is discussed below.

\section{SHIP NUCLEAR POWER PLANTS}

Contemporary ship nuclear power plants are used only on naval ships and for propulsion of Russian icebreakers of Arktika and Taimyr class [4,22]. It provides a tactical advantage over ships propelled by combustion engines. Nuclear submarines - from technical point of view - have practically unlimited combating range and submerge time. Aircraft carriers consume vast amount of energy for servicing airplanes and crews of even 6000 persons in number, they are almost self-sufficient "towns", and Russian icebreakers keep free way through Northern Path and riverways of Russian tundra $[20,23]$.

Lack of application of nuclear energy to merchant fleet results from a low profitability of contemporary ships fitted with nuclear propulsion, compared to conventionally propelled ones. It is connected first of all with high investment and operational costs. Crew of nuclear ship is even two times greater in number and must be highly skilled $[4,20]$.

Moreover, nuclear energy industry is often confronted with social resistance in spite of its high level of safety. This is caused by the fact that consequences of possible failures or disasters lead to long-lasting and serious hazards for people and the environment. However it should be stressed that the social resistance presently weakens and this is only nuclear energy which makes it possible to have reliable source of energy after running low conventional fuels [20,21,23].

\section{PWR REACTORS}

In present, PWR reactors are mainly applied to ship nuclear power plants $[4,23]$. Such solution is advantageous from point of view of economic investment planning. They are moderated, water-cooled reactors and their low values of operational temperature do not require use of heat - resistant materials. The reactors are of a high core power density owing to which core volume does not exceed $1 \mathrm{~m}^{3}$ also in ship applicable solutions $[4,22]$. However the high power density is not advantageous from the safety side because in case of a cooling system breakdown a violent evaporation of cooling water, fracture of reactor vessel and core melt-down, may happen. Among other drawbacks of PMR reactors may be numbered the fuel reloading operation which usually is associated with disassembling the whole reactor. The fuel reloading operation is carried out every 5 th or 10th year on average, that is connected with long-lasting overhauls resulting from several month long periods of reactor's cooling - down and - usually with the necessity of cutting openings in ship sides. Moreover nuclear power plants are characterized by a large mass of reactor (thickness of reactor vessel walls reaches even $200 \mathrm{~mm}$ because of high safety margin necessary due to contaminated water pressure up to $16 \mathrm{MPa}$ at $350{ }^{\circ} \mathrm{C}$ temperature) $[4,17]$. At so low parameters of reactor's cooling agent, power plants based on PWR reactors achieve low values of live steam parameters in steam cycle, which usually do not exceed $300^{\circ} \mathrm{C}$ and $4 \mathrm{MPa}$. It leads to obtaining a low value of thermodynamic efficiency not greater than 35\%. Live steam in the cycles fed by water- cooled reactors is saturated steam or overheated one in the range of $50 \mathrm{~K}[4,23]$. It results in the necessity of applying additional solutions to dewater expanding steam. The above mentioned drawbacks make that PWR reactors can be successfully substituted by HTR reactors (described below).

\section{HTR REACTORS}

HTR reactors (i.e. High Temperature Reactors) or VHTR ones (i.e. Very High Temperature Reactors) belong to a broad group of HTGR reactors (i.e. High Temperature Gas Reactors) whose first types were built as early as in the 1970s [4,23]. Their technology has been proved but not implemented mainly due to the then economic conditions. But, as it was already mentioned, today the technology is under intensive development [5].

The HTR reactors are equipped with a pebble bed reactor (i.e. Pebble Bed Reactor). Such reactor has form of a cylinder filled with TRISO fuel in the form of graphite balls. TRISO (i.e. TRiple coated ISOtropic fuel) is combined with fissile material particles of $0,5 \mathrm{~mm}$ diameter. It is usually uranium oxide of a low degree of enrichment (about 10\%) with an addition of radiothorium. The fuel particles are closed in three ceramic shells of total diameter of $0,92 \mathrm{~mm}$. The protection 
shells maintain their structure and tightness up to $2000{ }^{\circ} \mathrm{C}$ temperature [5]. TRISO particles are uniformly arranged within a graphite ball of $60 \mathrm{~mm}$ in diameter. In the case of such fuel parameters the reactor in question is filled up to $1 / 3$ of its volume with graphite balls which serve as a moderator.

The application of the pebble bed reactor is associated with many advantages, a. o. possible supplying with fuel of various compositions and enrichment degree (diversification of supply), very high level of fuel burn-up up to 100000 $\mathrm{MWd} / \mathrm{t}$ (for PWR reactors - abt. $45000 \mathrm{MWd} / \mathrm{t}$ ), that results from second fuel charging (one ball leaves the reactor every $30 \mathrm{~s}$ and is loaded again into it 15 times on average) [5]. This is made possible due to very easy procedure of reloading the fuel, which does not even require to shut-down the reactor. Moreover, in the case of a failure the reactor can be unloaded under gravity force only, and the fuel does not suffer any damage and can be loaded again into the reactor. In the case of loss of tightness of reactor's vessel a cooling agent leakage does not endanger people and the environment because helium, i.e. reactor cooling agent, does not undergo radioactive activation and gaseous products of fission maintain kept closed within fuel balls. Walls of the reactor may be only $50 \mathrm{~mm}$ thick because of a low pressure inside [4].

In gaseous reactors it is possible to make use of the hot reactor - cooling gas directly in Joule-Brayton cycle or gas-steam cycles. In case of such solution, in order to limit dimensions of ship power plant (especially its heat exchanger), it is advised to use helium as a cooling agent because its specific heat amounts as much as $5,193 \frac{\mathrm{kJ}}{\mathrm{kg} * K}$. As an alternative is used inexpensive carbon dioxide of specific heat equal to 1,292 $\frac{\mathrm{kJ}}{\mathrm{kg} * K}$. Helium is an expensive perfect gas which, because of a small size of its particles and low viscosity, makes keeping tightness of pressure installation troublesome, but , as it has been proved, use of it in steam generators multifold lowers their dimensions compared to steam boilers. Dimensions of such generators will be also advantageous compared to application of other gases (e.g. $\mathrm{CO}_{2}$ ), and their live steam parameters - much more higher than in the case of application of water. Moreover, a smaller mass flux of the cooling agent makes it possible to significantly reduce demand of power necessary to drive fans of reactor- cooling loop [7].

The use of HTR reactor- cooling gas to feed a steam generator makes it possible to reach supercritical parameters of steam cycle and to achieve this way high heat energy conversion efficiency. In the case of contemporary ship power plants their live steam parameters are as follows: $10 \mathrm{MPa}$ and $535^{\circ} \mathrm{C}$. It results in extensive "piling-up" temperature in steam generator that additionally improves heat exchange parameters and allows to decrease dimensions of the generator. Moreover, water present in steam cycle is not subjected to radioactive exposure $[16,19]$.

\section{VARIABLE OPERATIONAL CONDITIONS}

The necessity of operation under distinctly variable conditions is very characteristic for ship power plants. For stabilizing rotational speed of propulsion turbines an electric reduction gear may be applied. In consequence, additional losses are introduced as a result of electric energy conversion , but the efficiency characteristics in function of changes in rotational speed of screw propeller, are improved. Moreover, it makes application of back running unnecessary, and possible application of azimuth propellers may provide excellent manoeuvrability to ship. In this case schematic ship power plant diagram resembles that of stationary small-output power plants $[20,21,23]$.

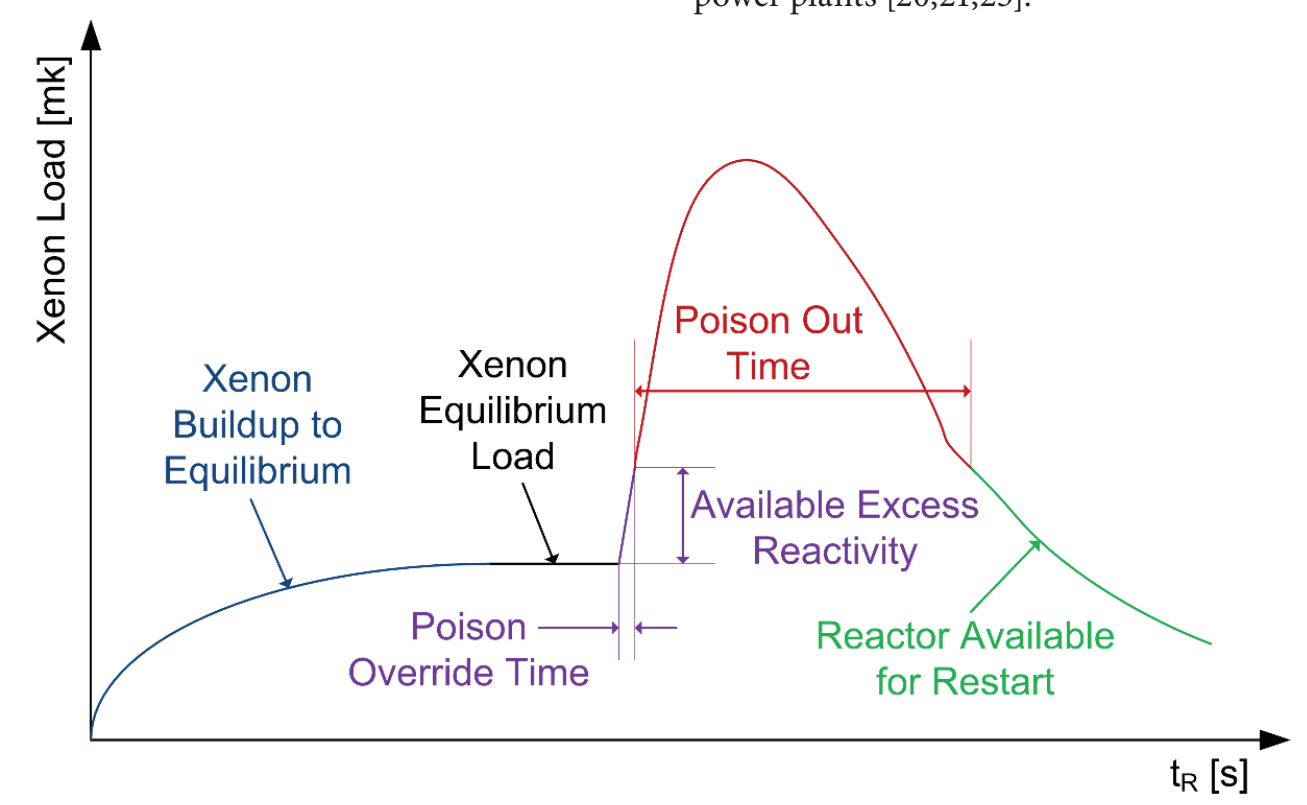

Fig.1. Simplified characteristics of reactivity losses as a result of Xe-135 poisoning during start-ups and power reduction [6] 


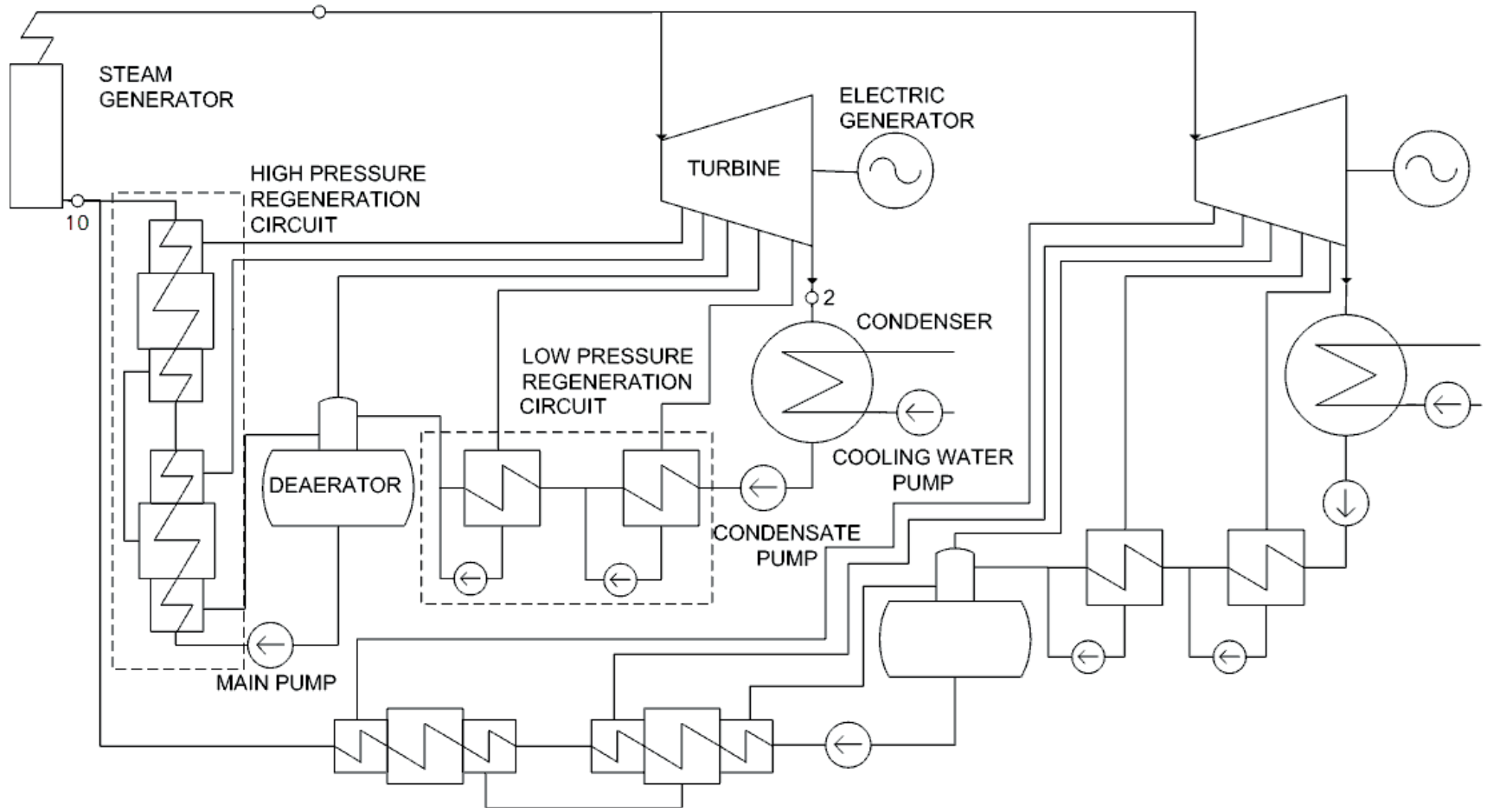

Fig. 2. Schematic thermodynamic diagram of the "twin" system of ship power plant

Another way to optimize parameters of ship power plants under variable operating conditions, which however interferes also cycle parameters, is application of control of rate of steam turbine condenser. It leads to some savings in amount of energy necessary to drive cooling - water pump and to prevention against condensate overcooling [8].

Amount of power generated in ship steam turbine is usually controlled by means of throttle governing. This is not a control desirable from the economic point of view as it introduces losses resulting from steam throttling. However it makes it possible to control turbine output in a broad range without changes in temperature distribution within turbine casing and steam extractions. Such control allows to conduct manoeuvres of the ship. However for the output control in longer time intervals, e.g. for keeping a given speed of a ship, slipping control is used. It consists in decreasing heat power of steam boiler by changing flux of energy delivered with fuel. And, in the case of water -cooled reactors such control is executed by tentative moderating the fissile reaction by means of control rods or introduction of neutron absorbers in the form of boric acid into fuel - cooling water. However it leads to drop of fuel temperature and rise of $\mathrm{Xe}-135$ concentration (xenon isotope). This is the so-called xenon poisoning phenomenon whose run is illustrated in Fig. 1 [6].

During rated power operation, xenon isotopes are burned out in the same quantity as that produced, hence their amount, expressed in the reactivity units $\mathrm{mk}$, reaches an appropriate level (Xenon Equilibrium Load). When Xe-135 concentration, as a result of output control process, causes Available Excess Reactivity to be exceeded, then fission chain reaction will start to extinct (Poison Out Time). To develop again the fission reaction is possible only if Xe-135 excessive amount is converted into other isotopes a smaller cross-section capable of absorbing neutrons generated during radioactive half-life period (Reactor Available for Restart). The radioactive half-life for Xe-135 is equal to $9,1 \mathrm{~h}[6,17]$.

HTR reactors are of a low core power density, namely on the level below $10 \mathrm{MW} / \mathrm{m}^{3}$. The feature, in association with negative reactivity, makes that at lowering power plant load heat flux absorbed from the reactor becomes also lower, fuel temperature rises and generated power drops. It was proved experimentally that in the case of full switching-off the cooling circulation loop, fuel balls reach their maximum temperature limited to $1600{ }^{\circ} \mathrm{C}$, and fissile reaction then starts to decay [5]. Heat energy generated during the entire process is absorbed by reactor walls and transferred to the atmosphere by natural circulation of air. Therefore there is no danger of melting the reactor core or protective barrier. Coolant pressure does not provide any risk of fracture to reactor's vessel. This mode of control has also two advantages: it protects reactor against xenon poisoning, and at a partial load live steam temperature can be kept on a constant level.

Therefore it should be unambiguously stated that HTR reactors ensure in every respect better operational parameters under variable operation conditions than PWR reactors.

\section{CONDITIONS OF ANALYSIS}

Design parameters of ship power plants are chosen in compliance with mission of a ship, its service speed, manoeuvrability and own demands of the ship such as: energy supply to refrigeration plant, living accommodations and objects for passenger needs. For the reasons two steamturbine cycles were taken into account in analyzing possible use of HTR reactors in ship steam power plants. First of them 
(called further "twin" system or cycle) is consisted of two identical, independent turbine sets fitted with a supply - water regenerative pre-heater (circuit). Schematic thermodynamic diagram of the system is presented in Fig. 2.

The other cycle consists a turbine set with interstage overheat and supply - water regenerative pre-heater. Schematic thermodynamic diagram of the cycle is presented in Fig. 3. The basic difference between the cycles in question is the distribution of power between propulsion turbines. Namely, in the "twin" system it is possible to reach full thermodynamic efficiency both under rated load and that equal to a half of the rated output. This is achieved at the expense of maximum thermodynamic efficiency which is higher in the case of application of interstage overheat.

Tab. 1. shows parameters of live steam, overheat and condenser. For both the cycles temperatures and pressures of the upper and lower heat source have been selected on the same level.

The cycle with interstage overheat has one regenerative exchanger more however it maintains the same heat exchange area for both the power plants. This ensures similar dimensions and masses for both the proposed power plants and makes more exact comparing them possible. Own demands of the power plants are the following: to drive the condensate and water supply pumps and reactor - cooling helium fans.

The above discussed solutions are advantageous because in case of a failure of one of the turbine sets it is still possible to reach a partial output. In the case of the "twin" cycle it
Tab.1 Steam parameters in characteristic points of the proposed steam cycles [20].

\begin{tabular}{|c|c|c|c|c|}
\hline Parameter & Symbol & Unit & $\begin{array}{l}\text { Cycle with inter- } \\
\text { stage overheat }\end{array}$ & $\begin{array}{l}\text { "Twin" } \\
\text { cycle }\end{array}$ \\
\hline $\begin{array}{c}\text { Temperature of } \\
\text { live steam }\end{array}$ & $t_{o}$ & ${ }^{\circ} \mathrm{C}$ & 535 & 535 \\
\hline $\begin{array}{c}\text { Pressure of live } \\
\text { steam }\end{array}$ & $\mathrm{p}_{0}$ & [bar] & 100 & 100 \\
\hline $\begin{array}{c}\text { Temperature } \\
\text { of steam from } \\
\text { interstage overheat }\end{array}$ & $t_{o^{\prime}}$ & ${ }^{\circ} \mathrm{C}$ & 535 & - \\
\hline $\begin{array}{c}\text { Pressure of steam } \\
\text { from inter-stage } \\
\text { overheat }\end{array}$ & $\mathrm{p}_{\mathrm{o}^{\prime}}$ & [bar] & 18 & - \\
\hline $\begin{array}{l}\text { Pressure in } \\
\text { condenser }\end{array}$ & $\mathrm{p}_{2}$ & [bar] & 0,05 & 0,05 \\
\hline $\begin{array}{l}\text { Number of } \\
\text { regenerative } \\
\text { exchangers }\end{array}$ & - & - & 5 & 4 \\
\hline
\end{tabular}

is possible to switch off one of the turbine sets by means of a quick-closing valve whose main function is to protect turbine against racing over a permissible rotational speed. In the case of the cycle with interstage overheat it is possible to keep in operation either its high-pressure or low-pressure turbine with the use of reducing-cooling stations which adjust steam parameters to demands of the low-pressure turbine or condenser.

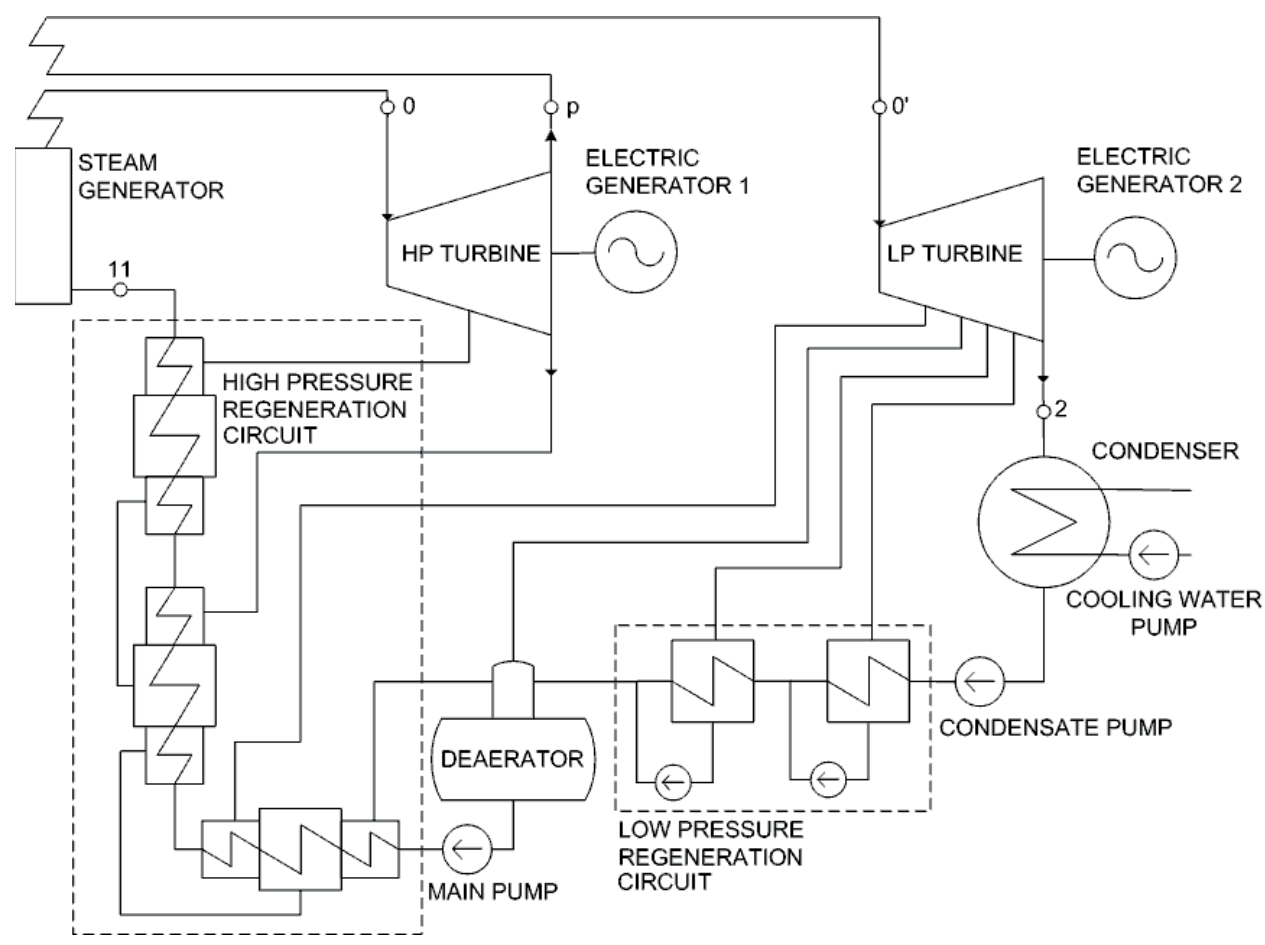

Fig. 3. Schematic thermodynamic diagram of the cycle of power plant with interstage steam overheat 


\section{MATHEMATICAL MODEL}

Steam parameters in the characteristic points of the thermal cycles in question in variable operational conditions were determined by using Flügl equation which describes steam flow capacity of a turbine [8]:

$$
\frac{m_{i}}{m_{i 0}}=\frac{p_{i}}{p_{i 0}} \sqrt{\frac{t_{i 0}}{t_{i}}} \sqrt{\frac{1-\left(\frac{p_{i+1}}{p_{1}}\right)^{2}}{1-\left(\frac{p_{i+10}}{p_{10}}\right)^{2}}}
$$

where "0" stands for a value in the state of rated load, and „i" - steam flux flowing behind i-th extraction point.

As intermediate pressure values rise or drop simultaneously the expression which describes the pressure ratio can be simplified according to (2) and neglected in Eq. (1) (behind the last stage of the turbine where $\mathrm{p}_{\mathrm{i}+1}$ is equal to the pressure $\mathrm{p}_{2}$ in the condenser).

$$
\frac{1-\left(\frac{p_{i+1}}{p_{1}}\right)^{2}}{1-\left(\frac{p_{i+10}}{p_{10}}\right)^{2}} \approx 1
$$

Eq. (1) obtains then the simplified form as follows :

$$
\frac{\dot{m}_{i}}{\dot{m}_{i 0}} \approx \frac{p_{i}}{p_{i 0}} \sqrt{\frac{t_{i 0}}{t_{i}}}
$$

Further calculations consist in performing subsequent iterations. In the first approximation it is assumed that change in steam mass flux in a given group of stages is the same as change in steam flux into turbine inlet.

$$
\frac{\dot{m}_{i}^{\prime}}{\dot{m}_{i 0}}=\frac{\dot{m}}{\dot{m}_{0}}
$$

In the current stage of calculations pressure in all extraction points changes proportionally to steam mass flux into turbine inlet, that is expressed as follows :

$$
\frac{p^{\prime} i}{p_{i 0}}=\frac{p^{\prime}}{p_{0}}=\frac{\dot{m}}{\dot{m}_{0}} \sqrt{\frac{t_{1}}{t_{10}}}
$$

Knowing value of the pressure p'i in subsequent extraction points one can determine, for a given load, a more exact value of steam mass flux flowing through the turbine in a considered state, by executing again thermodynamic calculations of the thermal cycle.

Net electric efficiency of the power plant is defined by the expression:

$$
\eta_{\text {netto }}=\frac{N_{\text {netto }}}{\dot{Q}_{S G}}
$$

Where, for the "twin" cycle, the net efficiency is defined by Eq. (7), and for that with inter-stage overheat - by Eq. (8).

$$
\begin{gathered}
\eta_{\text {netto }}=\frac{N_{G}-N_{O C}}{\dot{m}_{0}\left(i_{1}-i_{10}\right)} \\
\eta_{\text {netto }}=\frac{N_{G}-N_{O C}}{\dot{m}_{0}\left(i_{0}-i_{11}\right)+\dot{m}_{0 \prime}\left(i_{0 \prime}-i_{p}\right)}
\end{gathered}
$$

For the conducted analyses the following was additionally assumed:

- the generator efficiency characteristics - on the basis of the data for TGH-30 synchronous hydrogen-cooled generator (within the range of $0,95 \div 0,98$ for the considered load changes) [10]:

- the rated internal efficiency of the turbines was selected according to [9] as follows:

a. 0,87 - for the high pressure (HP) part of the cycle with interstage steam overheat;

b. 0,92 - for the low pressure (LP) part of the cycle with interstage steam overheat;

c. $\quad 0,90$ - for the turbine of the twin cycle.

The internal efficiency of turbines, at partial loads, is dependent on value of steam mass flux flowing through turbine, which was discussed in detail in [20].

- constant value of mechanical efficiency at a given rotational speed, equal to 0,99 , according to [9];

- constant value of efficiency of supply water, condensate and condenser cooling water pumps, equal to 0,85 ;

- constant values of efficiency of asynchronous motors ( dependent on rated power) in case of driving:

a. supply water pump, equal to 0,95

b. condensate pump, equal to 0,88

c. condenser cooling water pump, equal to 0,95

- constant efficiency value of helium fan, equal to 0,8 , and of asynchronous motor driving the fan, equal to 0,95 ;

- losses in regenerative heat exchangers were neglected, was assumed equal to 1,00 .

Some analytical models of steam cycle of ship nuclear power plants can be found in $[16,18]$, however they simplify much more cycle schemes and do not take into account e.g. the principle of steam flow capacity.

\section{RESULTS OF ANALYSIS OF POWER PLANT OPERATION}

On the basis of the taken model and assumptions, were determined characteristics of change in selected parameters of power plant under variable operational conditions for the selected output of the turbines, equal to $50 \mathrm{MW}$, measured on their shafts.

The obtained results of changes in the generator efficiency $\eta_{\mathrm{G}}$, net electric efficiency $\eta$ netto, average mechanical efficiency of HP and LP part of the turbine, $\eta_{\mathrm{T}}$, as well as the relative steam flux $m_{x} / m_{0}$, all in function of change in the power plant load $\mathrm{N}_{\mathrm{x}} / \mathrm{N}_{0}$ for the cycle with interstage overheat, are presented in Fig. 4. 


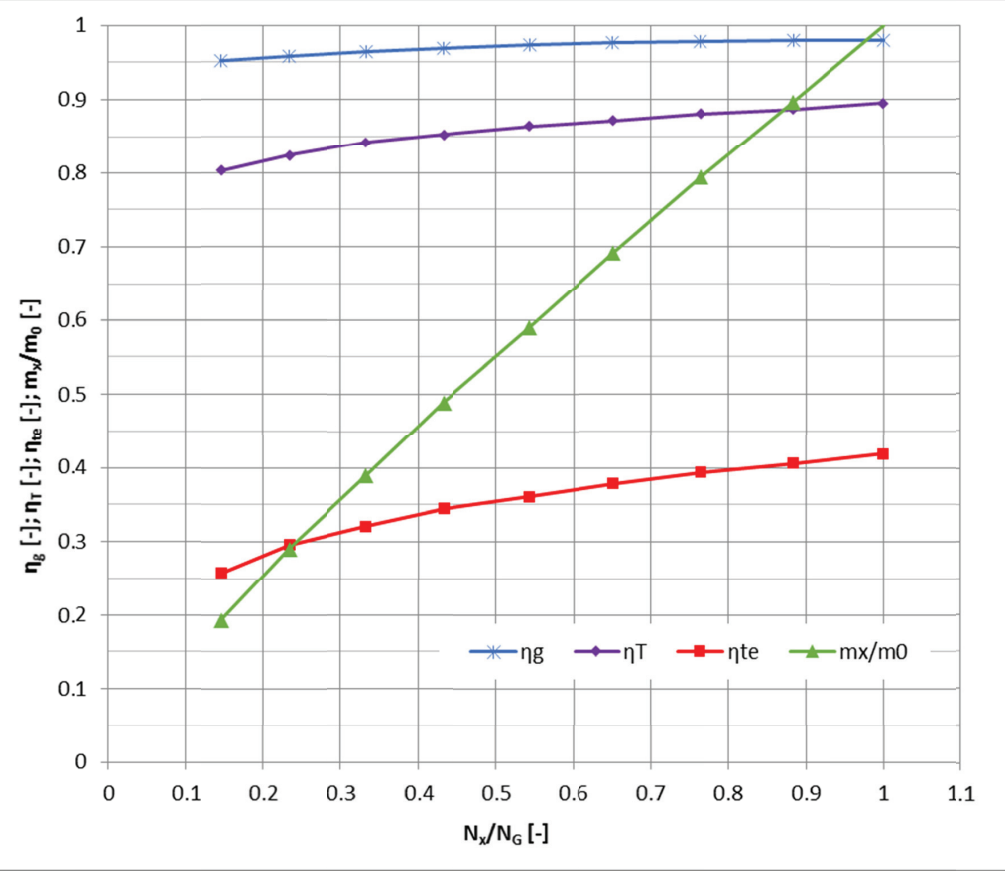

Fig. 4. Changes in the generator efficiency $\eta_{C}$, net electric efficiency $\eta$ netto, average mechanical efficiency of $H P$ and LP part of the turbine, $\eta_{T}$, as well as the relative steam flux $m_{x} / m_{0}$, all in function of change in the power plant load $N_{x} / N_{G}$ for the cycle with interstage overheat

load. In case of the cycle with interstage overheat, the parameter practically agrees with the relative steam mass flux $\mathrm{m}_{\mathrm{x}} / \mathrm{m}_{0}$ and for this reason it was omitted in Fig. 4.

The rated parameters of the analyzed power plants are presented in Tab. 2. On the basis of the data given in the diagrams of Fig. 4 and 5 as well as Tab. 2 it may be stated that the application of interstage steam overheat improves thermodynamic efficiency of thermal cycle of steam power plants, whereas the multiplication of turbine sets improves energy conversion efficiency in case of partial load. It should be stressed that the thing is the long-lasting partial load but not manoeuvring conditions.

\section{FINAL CONCLUSIONS}

As results from the performed literature review and calculations, the today used steam cycles in ship power plants could effectively interact with HTR reactors. The application of HTR reactors would improve this way energy conversion efficiency of ship nuclear power plants compared to the presently used PWR reactors, without introduction any significant changes in today implemented solutions of steam cycles.

The performed analyses of thermodynamic cycles of a power plant fitted with two-case steam turbine and interstage overheat as well as of two identical single-case turbines of cycle without overheat have demonstrated differences, at the same shaft power, both in of net electric power quantity developed by the power plant and in its efficiency values under partial loads.

The analysis of the efficiency characteristics presented in Fig. 4 and 5 and the data given in Tab. 1 and 2 leads to the conclusions that singlecase steam turbines operating under a simple thermodynamic cycle, doubled or multiplied in ship power plant, are able to ensure a higher energy conversion efficiency of power plant at partial loads. Such situations most often occur in case of passenger cruisers and other large passenger ships which consume vast amounts of energy even during mooring operations in ports. Such power plants may be also so designed as to deliver, from an additional turbine set, a peak power necessary e.g during manoeuvres or to ensure reaching the same

Fig.5 Changes in the generator efficiency $\eta_{G}$, net electric efficiency $\eta$ netto, average mechanical efficiency of the turbines, $\eta_{T}$, the relative steam flux $m_{x} / m_{0}$ and the relative turbine inlet pressure in function of changes in the power plant load $N_{x} / N_{G}$ for the 'twin' cycle

And, the calculation results for the "twin" cycle are given in Fig. 5. The diagram additionally contains the relative average pressure at turbine inlet in function of changes in power plant ship speed both in favourable and harsh weather conditions without any impact on thermodynamic efficiency of the power plant in rated operational conditions. Moreover, in this case a main propulsion electric reduction gear finds especially its application as it ensures a flexible electric power distribution as well as possible use of azimuth propellers which can provide excellent ship manoeuvrability. 
Tab. 2 Selected parameters of power plants under rated operational conditions at the same output of steam generator

\begin{tabular}{|c|c|c|c|c|}
\hline Parameter & Symbol & Unit & $\begin{array}{c}\text { Cycle with } \\
\text { interstage } \\
\text { overheat }\end{array}$ & “Twin" cycle \\
\hline $\begin{array}{c}\text { Output of } \\
\text { steam } \\
\text { generator } \\
\text { (reactor) }\end{array}$ & $\dot{Q}_{S G}$ & $\mathrm{MWt}$ & 112,40 & 120,41 \\
\hline $\begin{array}{c}\text { Net electric } \\
\text { output of } \\
\text { power plant }\end{array}$ & $\mathrm{N}_{\text {netto }}$ & $\mathrm{MWe}$ & 47,21 & 46,96 \\
\hline $\begin{array}{c}\text { Live steam } \\
\text { mass flux }\end{array}$ & $\mathrm{m}_{0}$ & $\frac{\mathrm{kg}}{\mathrm{s}}$ & 38,31 & 44,67 \\
\hline $\begin{array}{c}\text { Overheated } \\
\text { steam mass flux }\end{array}$ & $\mathrm{m}_{0^{\prime}}$ & $\frac{\mathrm{kg}}{\mathrm{s}}$ & 33,14 & - \\
\hline $\begin{array}{c}\text { Heat exchange } \\
\text { surface area }\end{array}$ & $\mathrm{F}_{\mathrm{w}}$ & $\mathrm{m}$ & 3022,75 & 3022,75 \\
\hline $\begin{array}{c}\text { Net electric } \\
\text { efficiency of } \\
\text { power plant }\end{array}$ & $\eta_{\text {netto }}$ & - & 0,42 & 0,39 \\
\hline
\end{tabular}

And, more complex ship power plants composed of two-case steam turbine and interstage overheat, show higher efficiency values under rated loads. As far as the presently possible application of nuclear energy to merchant ships are considered, the greatest chance is connected with the largest cargo ships operating on intercontinental routes. Therefore these are the considered power plants showing higher efficiency values under rated loads which have the greatest chance to be introduced in practice. Moreover, the highly efficient thermodynamic cycles in association with nuclear energy sources make it possible to resign from using economic speeds, that offers additional advantages to ship owners. Without a doubt, the analysis of the data presented in this paper constitutes a valuable source of information for preliminary analyses and choice of parameters for ship power plants based on nuclear energy.

The idea of application of high-temperature, graphitemoderated, helium - cooled nuclear reactors eliminates operational disadvantages of contemporary ship nuclear power plants by increasing their parameters over those of contemporary conventional steam power plants. Application of HTR reactors improves hence profitability of ship nuclear power plants compared to today used PWR reactors, increases their safety and lowers hazards to the environment. All the features make that application of HTR reactors could lead to more common use of nuclear energy in merchant shipbuilding.

\section{NOMENCLATURE}

$\mathrm{N}_{\text {netto }}$ - net electric output of power plant [MWel]

$\dot{Q}_{S G}$ - heat flux transferred to supply water in steam generator [MWth]

$\mathrm{N}_{\mathrm{G}}$ - total electric power measured at terminals of turbine

- set generators [MWel]

$\mathrm{N}_{\mathrm{x}}$ - a given power plant output measured at terminals of turbine - set generators [MWel]

$\mathrm{N}_{\mathrm{OC}}$ - total power for own demands of power plant to drive water pump and helium fan [MWel]

$\mathrm{F}_{\mathrm{w}}$ - heat exchange surface area of regenerative exchangers $\dot{m}_{0}$ - live steam flux at outlet from steam generator $\left[\frac{\mathrm{kg}}{\mathrm{s}}\right]$ $\dot{m}_{0}$ - live steam flux for interstage overheat $\left[\frac{\mathrm{kg}}{\mathrm{s}}\right]$

$\mathrm{i}_{1}$ - live steam enthalpy at outlet from steam generator in case of the "twin” cycle $\left[\frac{\mathrm{J}}{\mathrm{kg} * K}\right]$

$\mathrm{i}_{10}$ - enthalpy of supply water for steam generator in case of the "twin” cycle $\left[\frac{J}{k g * K}\right]$

$\mathrm{i}_{\mathrm{p}}$ - enthalpy of steam at outlet from high-pressure turbine casing, used for interstage overheat $\left[\frac{\mathrm{J}}{\mathrm{kg} * \mathrm{~K}}\right]$

$\mathrm{i}_{11}$ - enthalpy of supply water for steam generators in case of the cycle with interstage overheat $\left[\frac{\mathrm{J}}{\mathrm{kg} * \mathrm{~K}}\right]$

$\eta_{\text {netto }}-$ net electric efficiency of power plant

$\eta_{\mathrm{g}}$ - electric generator efficiency

$\eta_{\mathrm{T}}$ - average mechanical efficiency of turbine

$\mathrm{m}_{\mathrm{x}} / \mathrm{m}_{0}$ - relative live steam mass flux at inlet to turbine

$\mathrm{p}_{\mathrm{x}} / \mathrm{p}_{0}$ - relative live steam pressure at inlet to turbine

$\gamma_{i}$ - relative steam flux 


\section{BIBLIOGRAPHY}

1. PortalMorski.pl : Sea traffic statistical data (in Polish), http://www.portalmorski.pl/info/statystyki 14.02.2014.

2. Badur J.: Modelling of balanced combustion in gas turbines ( in Polish), Publ. IMP PAN, Gdańsk, 2003

3. Dzida M., Mucharski J.: On the possible increasing of efficiency of ship power plant with the system combined of marine diesel engine, gas turbine and steam turbine in case of main engine cooperation with the gas turbine fed in parallel and the steam turbine, Polish Maritime Research, No. 2 (60), 2009 , Vol. 16 p. $40 \div 44$

4. Jezierski G: Nuclar energy yesterday and to morrow ( in Polish), Scientific Technical Publishing House (Wydawnictwo Naukowo-Techniczne), Warsaw 2005

5. Department of Nuclear Science and Engineering, MIT: Modular Pebble Bed Reactor, http://web.mit.edu/ pebble-bed/14.02.2014

6. Kubowski J.: Problems of interaction between nuclear power plants and electric power network ( in Polish), Elektroenergetyka, No. 4 (670), 2010, pp. $218 \div 221$

7. Przybylski M., Głuch J.: Selected design and construction aspects of supercritical steam generators for high temperature reactors. Archives of Energetics, No 2 Vol. 42, 2012, pp. $113 \div 120$

8. Błaszczyk A., Głuch J., Gardzielewicz A.: Operating and economic conditions of cooling water control for marine steam turbine condenser, Polish Maritime Research, No. 3 (70), Vol. 18, 2011, pp. $48 \div 54$

9. Perycz S.: Gas and steam turbines (in Polish), Publishing House of Gdansk University of Technology ( Wydawnictwo Politechniki Gdańskiej), Gdańsk 1988

10. Stein Z.: Electric engines and drives ( in Polish), School and Pedagogical Publishers (Wydawnictwo Szkolne i Pedagogiczne ), Warszawa 1985

11. Dzida M.: On the possible increasing of efficiency of ship power plant with the system combined of marine diesel engine, gas turbine and steam turbine, at the main engine - steam turbine mode of cooperation, Polish Maritime Research, No.1 (59), 2009, Vol. 16, pp. $47 \div 52$

12. Dzida M., Giltler J., Dzida S.: On the possible increasing of efficiency of ship power plant with the system combined of marine diesel engine, gas turbine and steam turbine in case of main engine cooperation with the gas turbine fed in series and the steam turbine, Polish Maritime Research, No. 3 (61), 2009 Vol. 16,pp. $26 \div 31$
13. Hagling F.: Variable geometry gas turbines for improving the part-load performance of marine combined cycles Combined cycle performance, Applied Thermal Engineering, No. 31, 2011, pp. $467 \div 476$

14. WelayaY., Mosleh M., Ammar N.: Energy analysis of a combined solid oxide fuel cell with a steam turbine power plant for marine applications, J. Marine Sci. Appl., No. 12, 2013, pp. $473 \div 483$

15. Nisan S., Rouyer J., Marcetteau P., Duflo D.: SEMER: A simple code for the economic evaluation of nuclear and fossil energy-based power production systems, Nuclear Engineering and Design, No. 221, 2003, pp.301 $\div 313$

16. Geschwindta J., Lommers L., Southworth F., Shahrokhi F.: Performance and optimization of an HTR cogeneration system, Nuclear Engineering and Design, No. 251, 2012, pp. $297 \div 300$

17. Teichela H., Pouget-Abadie X.: How the European Pressurized Water Reactor fulfils the utility requirements,

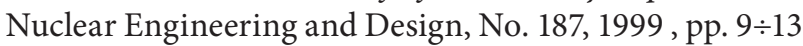

18. Asiedu-Boateng P., Akaho E., Nyarkob B., Yamoah S.: Modeling and simulation of cogeneration nuclear power plant for seawater desalination, Nuclear Engineering and Design, No. 242, 2012, pp.143 $\div 147$

19. Lommers L., Shahrokhi F., Mayer III J., Southworth F.: AREVA HTR concept for near-term deployment, Nuclear Engineering and Design, No. 251, 2012, pp.292 $\div 296$

20. Kowalczyk T.: Power engineering analysis of possible application of a ship steam power plant of 50MW output , equipped with a steam generator heated by helium agent cooling a high temperature nuclear reactor (in Polish), M.Sc. thesis, Gdańsk University of Technology, Gdańsk 2012

21. Smith C.: The energy challenge, Appl. Petrochem Res, No. 2, 2012 ,pp. $3 \div 6$

22. Sarkisov A., Vysotskii V., Bilashenko V., Barinov N., Kiselev A., Markarov V., Kulakov I., Lepekhin A., Petrunin V., Pichugin A., Krysov S.: Expected radiological and radioecological consequences of operating floating nuclear heat and power plants, Atomic Energy, Vol. 104, No. 3, 2008, pp. $237 \div 249$.

23. Hirdaris S., Cheng Y., Shallcross P., Bonafoux J., Carlson D., Prince B., Sarris G.: Considerations on the potential use of Nuclear Small Modular Reactor (SMR) technology for merchant marine propulsion, Ocean Engineering, No. 79, 2014, pp.101 $\div 130$ 
24. Staliński J., Szewalski R.: Analysis of impact of changes in technical-economic indices of ship power plants onto calculation results of economic profitability of ships ( in Polish), Acta Technica Gedanensia No. 1, 1963, Gdańsk 1963.

\section{CONTACT WITH THE AUTHOR}

Tomasz Kowalczyk, M. Sc.

Paweł Ziółkowski, M. Sc.

Energy Conversion Department, Institute of Fluid Flow Machinery, Polish Academy of Sciences

ul. Fiszera 14

80-231 Gdańsk

e-mail: tomek.kowalczyk@imp.gda.pl

pawel.ziolkowski@imp.gda.pl

Jerzy Głuch, Prof.

Department of Automatics and Turbine Propulsion, Faculty of Ocean Engineering and Ship Technology

Gdańsk University of Technology

11/12 Narutowicza St.

80 - 233 Gdańsk

\section{Poland}

